\title{
Tekmeria
}

Vol 10 (2011)

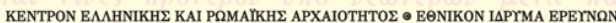
CENTRE DE RECHERCHE DE L'ANTIQUITE GRECQUE ET ROMAIN FONDATON NATOONAIE DE LA RECH GCHE SCIINTIFOOU

\section{Frequent Names and Local History}

ARGYRO B. TATAKI

doi: $\underline{10.12681 / \text { tekmeria.277 }}$

$T \epsilon \kappa \mu \eta \dot{\rho} \iota \alpha$

STMBOAEE ETHN IETOPA TOY EMAHNIKOY KAI PQMAIKO

KOEMOY • CONTRIBUTIONS TO THE HISTORY OF THE GREEK

AND ROMAN WORLD • CONTRIBUTION A L'HISTOIRE DU

GREC ET ROMAIN • BETTRÅGE ZUR GESCHICIE

DER GRIECHISCHEN UND RÓMISCHEN WELT

\section{0}

A

DIFFUSION DE BOCCARD - 11, RUE DE MEDICIS, 75006 PARIS 


\section{ARGYRO B. TATAKI}

\section{Frequent Names and Local History ${ }^{1}$}

Frequent names form the backbone of each onomasticon and are not the same everywhere. The factors that play a role in shaping differences in local onomastic preferences are connected with local mythology and history. The identification of the very frequent names can furthermore lead, to some extent, to an understanding of the local mentality. The evaluation of the evidence and the interpretation of frequent names had been a complicated procedure, now greatly facilitated thanks to the publication of the splendid volumes of $L G P N$ I-IV. The Greek onomasticon differs in the various areas of the Greek world not only for reasons resulting from local mythology and history but also because the evidence by which is formed in each place varies in degrees of completeness. One has to take into account the variety of sources covered by the evidence and to what degree each one is represented: official and private documents, lists of various types and the quantity of the evidence from funerary monuments, as has been pointed out already by P.M. Fraser in his discussion of the Delphian onomasticon. ${ }^{2}$ Furthermore, the ratio of the number of persons to the number of names gives some idea about the richness of the local onomasticon but also reflects the state of the evidence we are working with, that is the degree of completeness of the corpus of sources by which it is formed.

One would expect to find theophoric names of panhellenic distribution among the most frequent names in each place. It does not always happen this way. The uneven distribution of theophoric names has recently been discussed by Robert Parker. ${ }^{3}$ Names connected with local cults give a special character to some onomastica, as e.g. some Boeotian names discussed by Denis Knoepfler, ${ }^{4}$ but are rarely very frequent. Names connected with the function of a local sanctuary,

1. An earlier version of this paper was read during the International Conference "Nommer les hommes," held in Athens (December 2002).

2. Fraser, "Delphian Names" 141-47, 141-42.

3. Parker,"Theophoric Names" 53-79.

4. D. Knoepfler, "Oropodoros: Anthroponymy, Geography, History," in S. Hornblower and Elaine Matthews (eds), Greek Personal Names: their Value as Evidence (Oxford 2000) 81-98. 
but not properly theophoric, are sometimes frequent: e.g. the name M $\alpha \nu \tau i \alpha \varsigma$ at Delphi, occurring there 48 times, although not unknown elsewhere, ${ }^{5}$ is a reflexion of the function of the oracle of Apollo at Delphi and the epithets of the god:

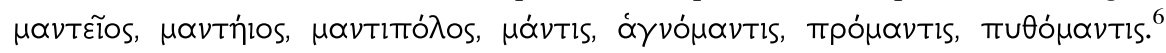
The frequency of this name is thus easily understood.

The most frequent name in a place sometimes does not belong to the usual categories, theophoric, or otherwise, of panhellenic names. For some areas it is however easy to provide a reasonable explanation for the popularity of a name. For example examination of the names of Beroea has shown that 'A $A \lambda \dot{\varepsilon} \xi \alpha \delta \rho \rho$ s was the most frequent name in the city. ${ }^{7}$ Now from the material we have in our files, as well as from $L G P N$ IV, we can tell that the same historical name was the most popular for Macedonia in general, and its popularity there is unsurprising especially if one also takes into account the rather late date of the bulk of the material we are dealing with. ${ }^{8}$ The most frequent name for the Greek world covered by LGPN IIV is a theophoric one, $\Delta$ lovúolos, with great variations in its frequency, the majority occurring in Attica; ${ }^{9}$ this is also easily understandable.

The appearance of ethnics as personal names, in the onomasticon of an area not corresponding geographically to them, can lead to some historical interpretations; they are usually not frequent but they do not have to be in order to assume e.g. the prestige of Sparta in Macedonia as reflected by the names $\wedge \alpha ́ k \omega \nu, \Lambda \alpha ́ k \varepsilon v \alpha$ and $\Sigma \pi \alpha \dot{\rho} \rho \tau \eta{ }^{10}$ The use of such names is usually more frequent in their own territory, particularly in the imperial period, as for example the names 'A $\tau \iota x o ́ s$

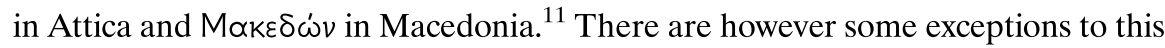
rule, as is shown by the Table accompanying the most recent contribution on the

5. $L G P N$ III.B; it occurs 14 times in Attica ( $L G P N$ II), 10 in Boeotia ( $L G P N$ III.B), 6 in the Aegean islands ( $L G P N$ I) and 5 in Arcadia ( $L G P N$ III.A).

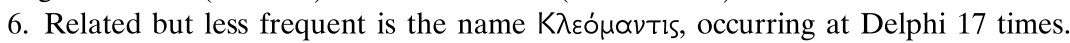
For the epithets of Apollo see C.F.H. Bruchmann, Epitheta Deorum (Leipzig 1893) in Roscher, Lexikon v. VII.

7. Tataki, Beroea 336-37, 408, 411-13, 415.

8. $L G P N$ IV under Macedonia: Alexandros 263 times cf. Dionysios 232 times; cf. the popularity of both at Athens in LGPN II and also Ph.E. Isett, "The Name Alexander at Athens," BN 15 (1980) 223-36.

9. Matthews, "Epiros" 176; Parker, "Theophoric Names" 66 n. 49.

10. Tataki, Beroea 342-43.

11. Attikos: $L G P N$ II 179 times compared to 31 in v. III.A, 8 in v. IV, 9 in v. I and 5 in v. III.B; Makedon: 46 in v. IV (37 in Macedonia), 12 in v. III.A, 7 in v. I, 4 in v. III.B, 3 in v. II. See also Fraser, "Ethnics" Table I. 
subject by P.M. Fraser. ${ }^{12}$ In another paper I have tried to explain the frequency of

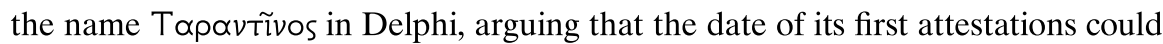
connect it with a possible visit there of a famous citizen of Taras, the Pythagorean Archytas, with a consequent fashion for the name in Delphi. ${ }^{13}$

The examination of the onomasticon of Taras was the next step in our attempt to gain a better understanding of the city by identifying its frequent names or, more precisely, by interpreting its onomastic preferences. The examination of the onomasticon of Taras, on the basis of $L G P N$ III.A, did not however give any fruitful results as far as frequent names are concerned. Excluding the persons dated to the Byzantine period, we counted a total of 457 persons bearing 367 names; most of them are attested only once, while those that are relatively frequent are quite

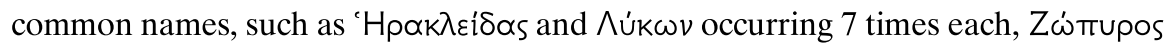

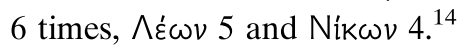

The sources for the formation of this onomasticon consist mostly of literary and numismatic evidence supplemented by a few inscriptions, including some on vases and loom weights. A lesson learned from this venture was that one has to have a substantial number of inscriptions in order to be able to deal with a more representative onomasticon. But there is something else in Taras that comes from the examination of the prosopography of the city, as we tried to outline it from the entries of $L G P N$ III.A: a long list of Pythagoreans, the longest formed by any city, a total of 43 persons, all listed by Iamblichos (VP 36, 267 lines 20-29). ${ }^{15}$ The name Archytas and most of the names of the other Pythagoreans appear only once in the onomasticon of their city.

We now move to Cyrenaica following Cleinias, one of the Pythagoreans of

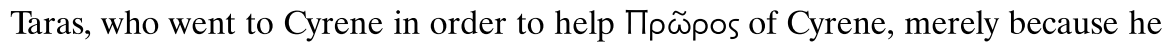
heard that he was a Pythagorean, when Proros lost his fortune during a political

12. Fraser,"Ethnics" 149-57, Table I.

13. Argyro B. Tataki, " $\sum \alpha \omega \nu$, "A $\theta \alpha \mu \beta$ os and other Names from $L G P N$ III.B," Tyche 16 (2001) 205-210. I should add here that the frequency of the name was already noted by Matthews, "Epiros" 179.

14. According to LGPN III.A; see also Addolorata Landi, Dialetti e interazione sociale in Magna Grecia (Napoli 1979) nos 175-208. A number of linguistically interesting names of Taras has been recently discussed by B. Ortega Villaro, "Observationes sobre la onomastica griega de Tarento y Heraclea," BN 33 (1998) 253-62.

15. See E.L. Minar, Early Pythagorean Politics (New York 1979) 86-94; H.Thesleff (ed.), The Pythagorean Texts of the Hellenistic Period, Acta Academiae Aboensis, Ser. A, 30, 1 (Abo 1965) passim; Freeman, Pre-Socratic Philosophers 244-45. See also St. Byz. s.v. Tá $\rho \propto \varsigma$. 
upheaval and became completely impoverished (Diod.X 4,1; Iamb., VP 33, 239 lines 1-8). ${ }^{16}$ Proros' name is very typical of Cyrene; it is the Cyrenaean form of

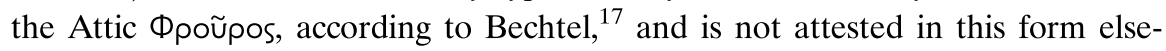
where. O. Masson has contributed greatly to the examination of the onomasticon of Cyrene and at least 8 of his studies deal with it; ${ }^{18}$ in our study we do not discuss any of the numerous names examined by him.

The earliest bearer of the name Proros was this Pythagorean philosopher of the 5th/4th century. Is it possible that because of him the name became popular in Cyrene? In order to answer this we will try to find similar examples of an early date to compare it with. We know about "fashions" for names, but at a later period, after the time of the Macedonian expansion. The distribution of Macedonian names throughout the world that expressed itself in the Greek koine is the clearest illustration of this new tendency in name giving. It is enough here to recall the popu-

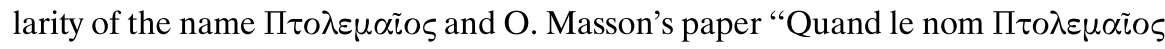
était à la mode." ${ }^{\prime 19}$ We return to Cyrene and the local name Proros to notice that the most famous of all the Olympic victors from Cyrene was also named Proros and is probably a more suitable candidate as a holder of a name that became quite popular in his city, occurring there 10 times and 2 more elsewhere in Cyrenaica. ${ }^{20}$ He was the victor in the stadion in 360 and in 356 B.C.; his victories are mentioned by Diodoros (XVI 2,1), in order to date the ascent of Philip to the throne of

16. Freeman, Pre-Socratic Philosophers 242.

17. F. Bechtel, Die historischen Personennamen des Griechischen (Halle 1917, repr. 1982) 515; see also Wolf. Aly, RE XXIII,1 (1957) 819.

18. There are in chronological order: "Remarques sur deux inscriptions de Cyrene et de Thera," RPh 1967 225-31; "L'inscription généalogique de Cyrène (SGDI 4859)," BCH 98 (1974) 263-70 = OGS I 211-18; "Quelques noms de Cyrénéens dans l'Egypte ptolémaique," in Le monde grec: Hommages à Claire Préaux (1975) 709-15 =OGS I 233-39; "Le nom de Battos, fondateur de Cyrène, et un groupe de mots grecs apparentes," Glotta 54 (1976) 84-98 =OGS I 269-83; "Une inscription ephébique de Ptolemais (Cyrénaïque)," ZPE 20 (1976) 87-100 = OGS I 243-56; "Grecs et Libyens en Cyrénaïque, d'apres les temoignages de l'épigraphie," Antiquité africaines 10 (1976) 49-62 = OGS I 285-98; "Notes d'anthroponymie grecque, IV: Les deux prêtresses Philyllio (Alexandrie et Cyrène)," RPh 57 (1983) 185-88 = OGS II 40912; "Remarques d'onomastique cyrénéenne: quelques noms masculine en - เ५," Quad. arch. Libya 12 (1987) 245-48 = OGS II 613-16.

19. ZPE 98 (1993) 157-67 = OGS III 149-59. For Macedonian names see also Tataki, Macedonians 34-36, 512-19.

20. $L G P N$ I. 
Macedonia and by Pausanias (X 2, 3), in connection with Philip's intervention in the Phokaian war. ${ }^{21}$

However, another Pythagorean's name, also of the 5th/4th century B.C.,

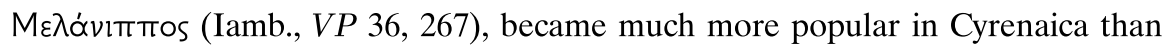
anywhere else, occurring a total of 35 times, 29 of them at Cyrene. ${ }^{22}$ There may, however, be doubt whether this evidence can be totally trusted, as we are dealing with a compound of $-\imath \pi \pi \circ \varsigma$ in Libyan territory, famous for its breeds of horses; other reasons could be argued for the attraction of such a name that was also used by Aeschylos as an epithet of the Night. ${ }^{23}$ Nevertheless, none of the other $-\imath \pi \pi \mathrm{o}$ names of Cyrene is as frequent as Melanippos. ${ }^{24}$

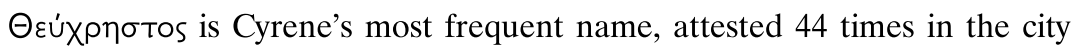
and 5 more in the rest of Cyrenaica. A comparison with Apollonios, another theophoric name, the most frequent of this category of names in the area, that totals 81 attestations in Cyrenaica, though only 23 are from the city, demonstrates the great frequency of the name..$^{25}$ Theuchrestos was one of the Olympic victors in the four-horse chariot race originating from the city; the name was also borne by his homonymous grandson, victor in the same sport, whose statue in Olympia was seen by Pausanias (VI 12, 7). ${ }^{26}$ The former was victor in 360 and the latter in 300 B.C. This very frequent name lead me to the examination of the other victors' names and the identification of those that became frequent at Cyrene, reasoning that their international fame might inspire a tendency for the adoption of their names by some Cyrenaean families. Although her citizens were famous for their excessive luxury (Aelian, $V H$ XII 30), and hedonism is one of the main principles of the

21. Moretti, Olympionikai nos 423, 430.

22. The other occurrences, on the basis of $L G P N$, are 26 in the Aegean islands, 11 of them from Rhodes, 5 at Athens, 4 in Boeotia, 4 in Thessaly, 2 on Sicily, 1 at Sparta and 1 in Illyria.

23. Aesch., Fr. 69,5; Athen. 469 F. See the discussion of - $1 \pi \pi 0$ names by Alexandra Anne Thompson, Studies in Greek Personal Names down to about 400 B.C. (Ph.D. Diss. Unpubl. Cambridge 1979) 162-67, 273-96 and also L. Dubois, "Hippolytos and Lysippos: Remarks on some Compounds in I $\pi \pi \mathrm{o}-$, - $-1 \pi \pi \mathrm{T}$, in Greek Personal Names," in S. Hornblower and Elaine Matthews (eds), Greek Personal Names: their Value as Evidence (Oxford 2000) 41-52.

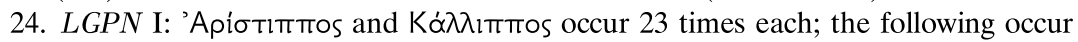

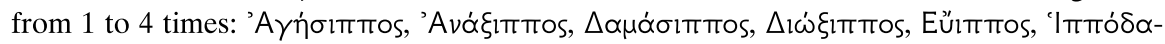

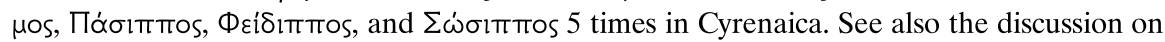
Libyan horses in F. Chamoux, Cyrène sous la monarchie des Battiades (Paris 1953) 234-35.

25. $L G P N \mathrm{I}$.

26. Moretti, Olympionikai nos 428, 508; W. Schwahn, RE V A,2 (1934) 1703 nos 1, 2. 
Cyrenaic school, the city also became celebrated for the victories of her citizens in the Olympic and other panhellenic games, as is indicated by the three Pythian odes of Pindar (4th, 5th and 9th), written for Cyrenaean victories at Delphi. One of the

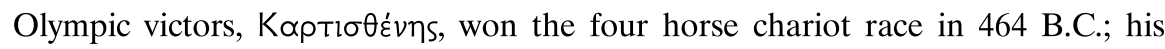

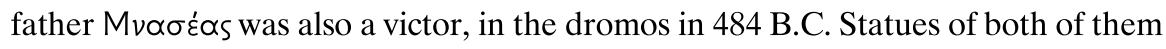
were seen by Pausanias in Olympia (VI 13, 7; 18, 1) and were dedicated by the son. ${ }^{27}$ Of the two, Kartisthenes, since he was the earliest bearer of a name that became characteristic of Cyrene and quite frequent (occurring 17 times in the city and 1 in Cyrenaica), ${ }^{28}$ might be considered one of the first, as far as we know, to

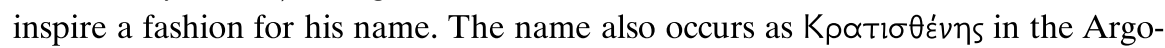
lid, where it is attested only once in the 4th cent. B.C. ${ }^{29}$

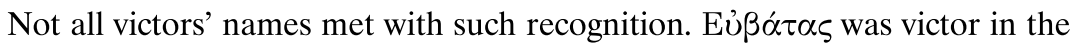
stadion in 408 B.C. ${ }^{30}$ According to Pausanias (VI 8, 3), he had learned from the oracle of Libya that he was going to be the victor in the stadion in Olympia so he had prepared his statue beforehand; Eubatas was thus able to dedicate it the same day he was proclaimed victor. According to Aelian's account ( $V H$ X 2), Lais, the most famous courtesan of her time, fell passionately in love with this remarkable character and, succeeding in her plans, married him after his victory. When they went to Cyrene she erected an enormous statue for him there. His victory is mentioned by both Diodoros (XIII 68, 1) and Xenophon (Hell. I, 2,1) for chronological purposes. His name however did not have the frequency one would expect; it occurs 7 times in Cyrenaica and is also attested 4 times on Thera, the mother city of Cyrene, once in Thessaly and there is 1 Eubates from S. Italy. ${ }^{31}$

After Cyrene we move to another very famous Apollo centre, Delphi, to focus on some Delphian names. Observations on the Delphian onomasticon and the definition of the epigraphic evidence on which it is formed were presented by Peter Fraser at the French School in Athens, in the conference commemorating the centennial of the excavations of Delphi. ${ }^{32}$ The Delphian onomasticon is very dis-

27. For both of them see Moretti, Olympionikai nos 257, 194; E. Honigmann, RE XI,2 (1922) 1659-60 and G. Reincke, RE XV,2 (1932) 2249-50 no 2.

28. $L G P N \mathrm{I}$.

29. $L G P N$ III.A.

30. Moretti, Olympionikai no 347 and no 421, for a homonymous victor in four horse chariot race in 364 B.C., considered by Moretti as identical to him; it is more likely that he was the grandson of the victor in stadion.

31. $L G P N$ I, III.B, III.A.

32. Fraser, "Delphian Names." 
tinct and characteristic and consists of many frequent local names that defy explanation. There are reasons to believe, as we will try to show, that these names are much older than their earliest occurrences at Delphi. A characteristic case is presented by the name Mévns, the most frequent at Delphi; it occurs 110 times, and is also known from scattered evidence throughout the Greek world, although is not a frequent name anywhere else; the volume of $L G P N$ that contains the most attestations, after Delphi, is v. I with 14 Meneses scattered on 10 different islands. ${ }^{33}$ The earliest attestation of the name for a Delphian dates in the 2 nd half of the 4th century (we have hardly anything before the 4th cent. from Delphi in any case). Earlier it appears on Keos in the 5th century, as the patronymic of a victor at Nemea. ${ }^{34}$ A Keian named Menes is included among 11 Keian sponsors to the shrines of Delphi, shortly after the middle of the 4th century; this is the earliest attestation of the name at Delphi. ${ }^{35}$ An earlier Menes, from Kamarina on Sicily, was the official in command who accused the generals of Akragas of treason before the assembly, a few months before the fall of Akragas to the Carthaginians in 406 B.C. (Diod. XIII 87, 5). The name however is much more ancient than this 5 th century personage. Menes was the name of a mythical figure killed by Neoptolemos (Quint. Smyrn. VIII 81); he was the son of a Kassandros, who was the leader of the Trojans from Karia. ${ }^{36}$ Neoptolemos, the son of Achilles, one of the warriors of the Wooden Horse, was killed by Apollo and buried at Delphi after the sack of Troy and his return; in another account of this story the hero was killed by Orestes. As Pindar says, in Paean VI 98-120, Apollo was angry with Neoptolemos for killing Priam and swore that he would not let him return home; he killed him when he visited Delphi. However Pindar (Nem. VII 34-47) gives also a different version saying that Neoptolemos was killed in a quarrel over sacrificial meat. According to Euripides' Orestes (Eur., Or. 1655), Apollo said that he was doomed to die by Delphian swords. We know that Pausanias visited the hero's tomb in Delphi (X 24,4-6). Neoptolemos' name, although widespread in the Greek world ${ }^{37}$ is absent from

33. Athens comes next with 10 occurrences, Thessaly with 5 , and there are 1 each from Boeotia, Locris, Argos and Kamarina, according to $L G P N$; it is also the name of one of Alexander's bodyguards from Pella: F. Geyer, RE XV,1 (1931); Tataki, Macedonians 157 no 61.

34. IG XII Suppl. p. 114, 608 line 20.

35. FD III.5, 6B line 12 .

36. A. Modrze, $R E X V, 1849$ no 3; and Kreusa no 5 in Roscher, Lexicon s.v.

37. Its most frequent occurrences are at Athens, 12 times; in Epiros and in Thessaly 10 times each, and 20 more come from several Aegean islands, according to the $L G P N$. 
the Delphian onomasticon, not surprisingly after this dramatic story, while the name of a man killed by him, Menes, became very popular. How can this be explained? And is there an explanation? The possibility that a bearer of this name became famous at some point for some reason and people started giving it to their children is and will remain a reasonable guess.

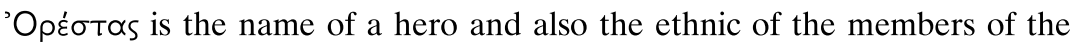
Molossikon ethnos and of a city in Euboea, according to Stephanos of Byzantium, while, according to the same source, the ethnic for Orestis, a region of Upper Macedonia, is Orestiaios. Epigraphic evidence has shown that the same ethnic was also used by the Macedonian Orestai. ${ }^{38}$ The hero is closely connected with the oracle as well as Apollo himself and that gives some explanation for the frequency of the name in Delphi, where it occurs 30 times from the 4 th to the 1 st century B.C. This very old name is not unknown elsewhere but it is not frequent, with the exception of Macedonia, where occurs a total of 23 times; its next most frequent appearance is 8 times in Thessaly. ${ }^{39}$ The oracle ordering him to kill his mother and her lover, in order to take revenge for his father's assassination upon his return from Troy, was given to Orestes at Delphi. Apollo himself appears in Aeschylos' Eumenidae supporting Orestes who had arrived at the temple as a suppliant (hiketes); he was finally saved thanks to the intervention of Athena, one of the leading gods at Delphi. In Eurypides, Orestes the hero is saved by Apollo (Eur., Or. 1677-90).

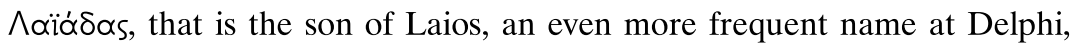
borne by 40 Delphians, occurs only four times elsewhere, in Lokris, Thessaly, Cyrene and Megalopolis, from where its earliest attestation comes (1st half of the 4th century). ${ }^{40}$ The son of Laios was Oedipous; Laiadas is how the hero is called by Ovid (Metam. VII 759). The hero's name, loaded with fate, is unsurprisingly not attested anywhere. Although its first appearance at Delphi is quite late, in 172 B.C., and its latest date is from the 1st cent. A.D., Laiadas is certainly a much older name and must be connected with Delphic mythology, since it was at Delphi that the oracle for the tragic hero was given, an oracle that he tried but could not avoid (Aesch., Sept. 745-49; Soph., OT 1329-30; Soph., OC 84-90). The name does

38. The earliest comes from a dedication on Delos: IG IX 4, 1118; see also Th. Rizakis - J. Touratsoglou, Epigraphes Ano Makedonias (Athens 1985) 188 line 3 and the discussion in M.B. Hatzopoulos, Macedonian Institutions under the Kings ("M $\varepsilon \lambda \varepsilon \tau \dot{\eta} \mu \alpha \tau \alpha$ " 22; Athens 1996) I 82.

39. $L G P N$ IV and III.B.

40. According to the $L G P N$. 
not belong to the category of heroic names that became popular in the imperial period, as its absence from the Greek names of Rome indicates. ${ }^{41}$

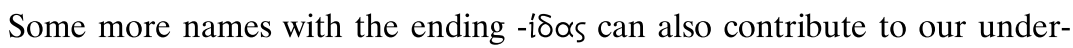

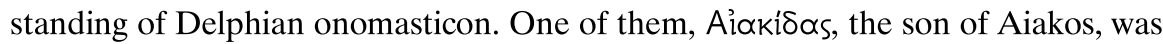
borne by 29 Delphians. Aiakos was one of the sons of Zeus, a hero of Aigina and one of the judges of the Underworld; he assisted Apollo and Poseidon in building the walls of Laomedon's Troy (Pindar, Ol. 8). He was the father of Peleus, grandfather of Achilles; both these heroes are called Aiakides in the Homeric poems, but that does not necessarily mean that the frequent presence of the name at Delphi reflects the memory of any of them. Supporting this connection is another name connected with the Myrmidons that is also present among the Delphian names; it is

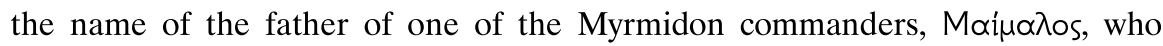

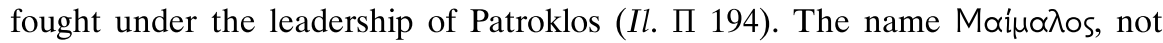
known elsewhere, is attested 5 times at Delphi. ${ }^{42}$ A more convincing explanation, however, for the popularity of the name Aiakidas at Delphi is that connected with Aiakos' illegitimate son Phokos. When Phokos was killed by his brothers his name was given to Phokis, a land in which his sons settled. Although the name of the hero, $\Phi \tilde{\omega} \mathrm{Kos}^{43}{ }^{43}$ and its derivatives exist in the Greek onomasticon in general (e.g.

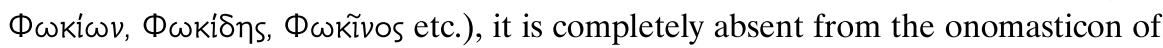
Delphi and from the rest of Phokis. Pausanias' description of Phokis starts with a reference to Phokos (X 1,1), who was portrayed as a young man by Polygnotos in the Knidian hall of Delphi (X 304). The name is derived from the word phoke, meaning seal, and was given to the hero by his father when his mother, a Nereid, transformed herself into a seal in order to avoid the passion of his father for her. Similar to the case of Oedipous = Laiadas the name of the hero was transmitted indirectly as Aiakidas, a very rare name elsewhere (once each in Thessaly, Epiros, and Cephalenia, twice in Aetolia, and there is one Aiakos on Crete). ${ }^{44}$

Another name connected with Phokis and its past is Boú $\lambda \omega v$, the name of the founder of Boulis, a city of Phokis; it is also a very frequent name, occurring 40 times at Delphi, compared to 18 in Attica, 8 on Delos and 2 in Lokris. ${ }^{45}$

41. H. Solin, Die griechischen Personennamen in Rom, I-III (Berlin-New York 1982).

42. See the discussion of the name in Fraser, "Delphian Names" 143-44.

43. According to the $L G P N$ there are 12 at Athens, 4 on different islands, 1 in Boeotia and 1 in S. Italy.

44. According to the $L G P N$.

45. Steph. Byz. s.v.; according to the $L G P N$. 
'EX₹kp $\alpha t i \delta \alpha s$ is another name formed as a patronymic (like Laiadas and Aiakidas discussed already), that also seems to have some connection with Delphi's past. It probably echoes the presence at Delphi of Echekrates, a Thessalian who fell in love with the young and beautiful Pythia, the woman who administered the oracle, and raped her, a fact that led the Delphians to introduce a law according to which the oracle should be given by a woman over 50 years old (Diod. XVI 26, 6). The name was borne by 14 Delphians and, not surprisingly, since Echekrates was a Thessalian, the name is attested 7 times in Thessaly and only very rarely

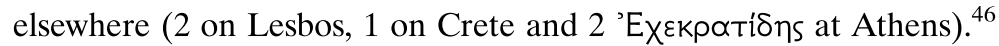

An interesting case in the same category of patronymics is the name 'Ava$\xi \alpha \nu \delta$ pi $\delta \propto$ s. The earlier bearers of the name are included in both royal houses of Sparta, ${ }^{47}$ one of them dated in the 7th century. The second reigned between 550516 B.C.; at this time inquirers were sent to Delphi to seek the intervention of the god in the war against Tegea. At this same time Croesus asked for an alliance with Sparta, after having repeatedly consulted the Pythian oracle and after having sent innumerable gifts to the temple, as well as gifts for each of the Delphians (Hdt. I 54). The Lacedaemonian king's name became quite frequent at Delphi, occurring 18 times, while it is rare elsewhere ${ }^{48}$ and was not borne by ordinary Spartans. It can only be conjectured at this point that the king personally visited Delphi.

With this last name, 'A $\mathrm{v} \propto \xi \alpha \nu \delta \rho i \delta \alpha$ s, we are introduced to the Peloponnesian connection and its traces in the onomasticon of Delphi, discussed already by P. Fraser. ${ }^{49}$ The name $\Delta \alpha \mu \varepsilon \dot{v} \eta s$, borne by 21 Delphians, offers an interesting example in this direction; it is the contracted form of $\Delta \alpha \ddot{\mu} \mu \varepsilon \dot{v} \eta \bar{s}$, the name borne by one of the sons of Tisamenos who, with his brothers, led the settlement of the Achaeans in Achaea (Paus. VII 6,2). The name is not unknown elsewhere but is nowhere frequent, occurring e.g. 5 times at Athens, 3 in Thessaly, 2 in Cyrenaika etc. ${ }^{50}$ and is completely absent from Achaea. Connections with Achaea are revealed by

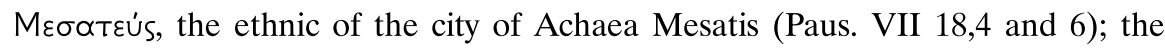

46. On the basis of $L G P N^{\text {'Ex }}$ हkpótms is more frequent: $L G P N$ I 9 times, II 5 times, III.A 16 times, III.B 13 times.

47. P. Poralla, Prosopographie der Lakedaimonier bis auf die Zeit Alexanders des Grossen (Breslau 1913, repr. Rome 1966), 2nd ed. by A.S. Bradford, A Prosopography of Lacedaemonians (1985) nos 80, 81.

48. Three times on Rhodes, 1 on Kos and ending in $-\eta \varsigma 3$ times at Athens, 3 on Thasos, according to the $L G P N$.

49. Fraser, "Delphian Names" 145-47.

50. According to the $L G P N$. 
name, which is also an epithet of Dionysos (Paus. VII 21,6), is relatively frequent at Delphi, occurring there 6 times, when account is taken of its absence elsewhere.

With the presence of one more very frequent name at Delphi we are led to another place that must have played an important role in Delphian history or the formation of the local mentality. It points to the Sicilian city Akragas. The name is 'E $\mu \mu \varepsilon v i \delta \propto s$, which occurs 36 times; it originates from the Emmenidae, ancestors of Theron and Xenokrates of Akragas. ${ }^{51}$ The Emmenidae were descended from Cadmos, as well as Laiadas (=Oedipus), whom we have discussed already. The name is not frequent elsewhere. ${ }^{52}$

The last Delphian name we are going to discuss is the name 'A $\chi \propto \mu \mu \varepsilon$ ' $\eta$, borne by 9 persons, from the 4th to the middle of the 3rd century. This was the name of the earliest of Cyrus' ancestors, and although this sacred place escaped the Persian threat, it was loaded with offerings donated after the Persian wars (Paus. X $15,1 ; 16,6 ; 18,1 ; 19,4)$. Why anyone in such an environment would name his son Achaemenes we will never be able to understand. The name is not attested elsewhere outside Delphi.

After Delphi we move to another very famous Apollo centre, Delos. Delos' rich onomasticon has been studied by Cl.Vial, who dedicated a chapter of her work Délos Indépendante to its examination, and more recently by O. Masson. ${ }^{53}$ Vial's discussion is focused on the many ethnics used as personal names, on some characteristic theophoric names, and on the originality of the Delian onomasticon as manifested by some rare names. Masson discussed and tried to interpret the large variety of names derived from animal names, rare feminine names, diminutives, some characteristic endings, almost everything worth discussing in an onomasticon.

The most frequent names of Delos are theophoric names of panhellenic distribution; it is not without interest here to compare their frequency to that of the theophoric names of Delphi since the quantity of the material is in both places the same, as has been pointed out already by P.M. Fraser, consisting of 7.000 individuals in each place. $^{54}$

There are 116 Dionysioi on Delos, compared to 46 at Delphi, 64 Apollonioi

51. H. Swoboda, $R E$ V,2 (1905) 2498-2500.

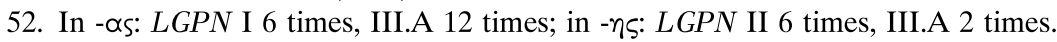

53. Vial, Délos 305- 315; O. Masson, "Les anthroponymes grecs à Délos," Comptes et inventaires dans la cité grecque, Actes du Colloque International de Neuchatel en l'honneur de J. Treheux (ed. D. Knoepfler), (Neuchatel-Genève 1988) 71-80 = OGS III 10-19.

54. Fraser, "Delphian Names" 141. 
compared to 8 at Delphi, 62 Demetrioi from Delos but only 11 from Delphi, 57 Apollodoroi compared to 9 from Delphi, 54 Diodotoi but none from Delphi. There are however some exceptions to this pattern, and we have 69 Diodoroi at Delphi compared to 15 on Delos and 37 Athenions at Delphi compared to 1 on Delos. ${ }^{55}$ The second most frequent name for a Delian after the theophoric names is T $\eta$ $\lambda \varepsilon \dot{\mu} \mu \eta \sigma \tau$ \% , occurring 36 times; the earliest dates from 374 B.C., the latest from 170

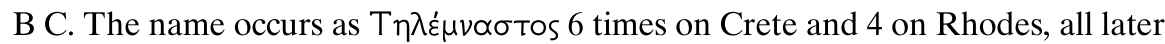
than the early ones of Delos. ${ }^{56}$ It is borne by members of one of the important families of the island, ${ }^{57}$ but we found no historical context that might be associated with its frequency.

The next most frequent name on Delos is $\Phi_{i} \lambda \lambda_{15}$, occurring 35 times; the name is known elsewhere but is nowhere frequent; in Boeotia it is attested 8 times ( 7 of them ending in $-\varepsilon \iota \varsigma$ ), 10 in the Peloponnese and 1, of the 3rd century B.C., comes from Athens. ${ }^{58}$ A well-known Delian musician of the 4th century is among the earliest bearers of the name. ${ }^{59}$ Music played a very important role in the festivals of Delos; the Delian maidens, famous in antiquity, sang and danced to Apollo, Leto and Artemis. In his cult statue at Delos Apollo held a bow in his right hand and in his left the Graces, each with a musical instrument. ${ }^{60}$ We know of hymns performed at Apollo's festival as early as the middle of the 8th century. In contrast with Delphi there are no pieces of music preserved from Delos: only some ivory and bone flutes have been found. ${ }^{61}$ The Delian Phillis wrote a work On Music in which he describes different kinds of string instruments, one on Flute Players and one On Tempos; the little we know about him comes from Athenaeos (XIV 634D, 636B; I 21F and FGH IIB p. 1021). As we learn from Plutarch's disputed treatise On Music (Mor. 1135F), Apollo was the inventor of the music of the aulos as well as of that of the lyre. Phillis said that the harp-singers of old permitted themselves a few movements of the face, but more with the feet, both in marching and in dance

55. LGPN I and III.B; cf. Parker, "Theophoric Names" 64-66.

56. $L G P N \mathrm{I}$.

57. Vial, Délos 279, 305, 412 .

58. $L G P N$.

59. M. Wegner, RE XIX,2 (1938) 2430; see also Barker, Musical Writings I 293, 297, 303; Annie Bélis, Les Musiciens dans l'Antiquité (Paris 1999) 44.

60. Barker, Musical Writings I 18, 38-41, 78, 219, 234 and n. 185, 274; W.D. Anderson, Music and Musicians in Ancient Greece (Ithaca and London 1994) 26, 59, 61.

61. W. Deonna, Le mobilier Délien, EAD XVIII,2 (Paris 1938) 324-25, pl. XCII nos 812-15; cf. CID III. 
steps. In a place where music was so important it is not surprising that a famous musician, who must have been not only a composer but also a performer, inspired a fashion for his name.

An ethnic $\Phi \omega x \alpha \iota \varepsilon u ́ s$ attested 33 times on Delos and only once on Tenos is one of the most frequent names of the island; as has been pointed out by C. Vial, its holders belong to many Delian families, ${ }^{62}$ but there is evidence neither for any historical event or myth that might connect the Ionian Phokaia to Delos nor for any commercial relations between them. The Phokaians were famous navigators and this naturally must have been admired by the Delians. An outstanding figure originating from this city may have caused the adoption of his ethnic as a popular Delian personal name. Such a figure was Dionysios of Phokaia, ${ }^{63}$ the man put in charge of the Ionian fleet before the naval battle of Lade, although his city participated with three ships only, in a total of 353, against a Persian force of 600 ships. The Ionians could not stand the discipline and hard training that Dionysios tried to enforce on them and consequently were badly defeated; Dionysios sailed away to Phoinice and to Sicily with three enemy ships that he had captured (Hdt. VI 11, 12, 17). If his personal name had been more distinctive and easily recognisable he might have been commemorated by it; having a very common and for that reason very unsuitable name for preserving the memory of such a distinguished personage, his name had to be substituted with his ethnic. The evidence we have is certainly later; it ranges from a little before the 4 th century to the 2 nd century B.C. Is this really important? What do we know after all about name giving in early 5 th century Delos or for most of the other places at that time?

\section{List of names discussed}

\begin{tabular}{|c|c|}
\hline 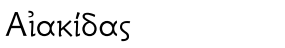 & 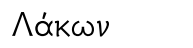 \\
\hline${ }^{\prime} A \lambda \varepsilon \dot{\varepsilon} \xi \alpha \nu \delta \rho \circ{ }^{\prime}$ & $\Lambda \varepsilon \dot{\varepsilon} \omega \nu$ \\
\hline 'Av $v \xi \alpha v \delta \rho i \delta \alpha \varsigma$ & 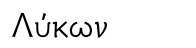 \\
\hline Apollonioi & 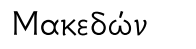 \\
\hline Apollodoroi & 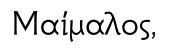 \\
\hline 'Attikós & Mavtias \\
\hline 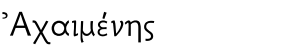 & 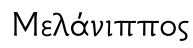 \\
\hline 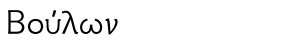 & 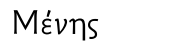 \\
\hline$\Delta \alpha \mu \varepsilon \dot{v} \eta \varsigma, \Delta \propto \ddot{\mu} \mu \varepsilon \dot{v \eta}$ & 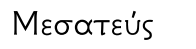 \\
\hline
\end{tabular}

62. Vial, Delos 310-11.

63. J. Kirchner, $R E$ V,1 (1901) 911 no 54. 


\begin{tabular}{|c|c|}
\hline Demetrioi & 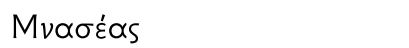 \\
\hline Diodoroi & Nikwv \\
\hline Diodotoi & 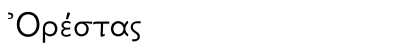 \\
\hline Dionysioi & 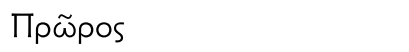 \\
\hline 'E $\mu \mu \varepsilon v i \delta \propto s$ & 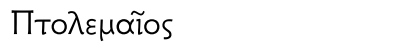 \\
\hline Eủßótas & $\sum \pi \alpha \dot{\rho} \rho \eta$. \\
\hline 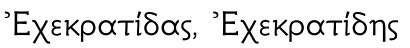 & 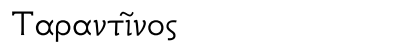 \\
\hline Zútrupos & 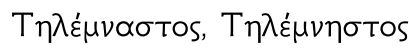 \\
\hline 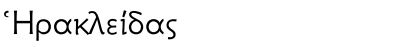 & $\Phi i \lambda \lambda_{15}$ \\
\hline 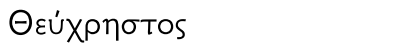 & Фpoũpos \\
\hline 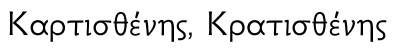 & 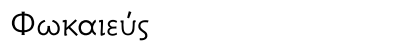 \\
\hline 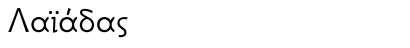 & $\Phi \omega k i \omega \nu, \Phi \omega k i \delta \eta s$ \\
\hline 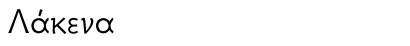 & $\Phi \tilde{\omega K}$ KOS \\
\hline
\end{tabular}

\section{Summary}

Frequent names form the backbone of each onomasticon and are not the same everywhere. The factors that play a role in shaping differences in local onomastic preferences are connected with local mythology and history.

Mention is made on theophoric names and ethnics used as personal names. The names of Taras are discussed in an attempt to understand the frequent appearance of the ethnic of this city at Delphi; it is followed by the examination of frequent names in Cyrenaica among which are included names of Pythagorean philosophers and Olympic victors. Special attention is given to the frequent names of Delphi connected with Delphian mythology and also reflecting historical facts. Next follows discussion of the names of the other famous Apollo centre, Delos, where appropriately the name of a Delian musician became very popular. The paper ends with an attempt to explain the popularity of the ethnic of the Ionian city Phokaia on the same island.

\author{
Barker, Musical Writings \\ Fraser, "Delphian Names" \\ Fraser, "Ethnics"
}

Freeman, Pre-Socratic Philosophers

\section{Abbreviations}

A. Barker, Greek Musical Writings I (Cambridge 1984) P.M. Fraser, "Delphian Names," Delphes cent ans après la grand fouille, BCH Suppl. 36 (2000) 141-47.

P.M. Fraser, "Ethnics as Personal Names", in S. Hornblower and Elaine Matthews (eds), Greek Personal Names: their Value as Evidence (Oxford 2000) 149-57, Kathleen Freeman, The Pre-Socratic Philosophers (Oxford 1946). 
Moretti, Olympionikai

Parker, "Theophoric Names"

Roscher, Lexicon

Tataki, Beroea

Tataki, Macedonians

Vial, Délos
L. Moretti, Olympionikai (Rome 1957)

R. Parker, "Theophoric Names and the History of Greek Religion," in S. Hornblower and Elaine Matthews (eds), Greek Personal Names: their Value as Evidence (Oxford 2000) 53-79.

W.H. Roscher, Lexikon der griechischen und römischen Mythologie VII.

Argyro B. Tataki, Ancient Beroea: Prosopography and Society ("M $\varepsilon \lambda \varepsilon \tau \eta \dot{\mu} \mu \tau \alpha$ " 8; Athens 1988)

Argyro B. Tataki, Macedonians Abroad ("M $\varepsilon \lambda \varepsilon \tau \eta \dot{\mu} \mu \alpha \tau \alpha$ " 26; Athens 1998).

Claude Vial, Délos Indépendante BCH Suppl. X (Paris 1984). 